\title{
Dendritic Cell-Lymphocyte Clusters that Form Spontaneously in Rheumatoid Arthritis Synovial Effusions Differ from Clusters Formed in Human Mixed Leukocyte Reactions
}

\author{
Van Tsai and Nathan J. Zvaifler \\ Department of Medicine, Rheumatology Division, University of California, San Diego, San Diego, California 92103
}

\begin{abstract}
Lymphocytes cluster about dendritic cells (DC) spontaneously in $48 \mathrm{~h}$ cultures of rheumatoid arthritis synovial fluid (RA SF) mononuclear cells and in peripheral blood autologous or allogeneic mixed leukocyte reactions. In the latter case, the clusters are predominantly CD4 $+\mathrm{T}$ cells $(\mathrm{T} 4 / \mathrm{T8}>5)$ and with time progress into blastic cells that express IL-2 (Tac) and/or transferrin (T9) receptors. In contrast, the clusters in RA SF cultures have a T4/T8 ratio of $<1$ and a majority of the T8 cells coexpress the Leu 7 marker. $T$ cells in these clusters remain inert and with time the clusters disintegrate. Addition of IL-1, IL-2, or IFN-gamma alone or in combination had no effect on RA SF clusters but $T$ cells became blastic when exposed to $10 \%$ RA SF. Mixing experiments using RA SF DC with normal $T$ cells and RA $T$ cells with normal $D C$ show that both RA SF DC and T cells are immunofunctional. In addition, clusters of RA SF from a patient with active tuberculosis proliferated vigorously to PPD. Therefore, the unique RA SF cluster profile may reflect the memory nature of the RA SF T cells resulting in a paucity of $T$ cells that are responsive to autologous stimulation. However, an immunosuppressive role for the double-labeled (CD8 and Leu 7) cells has not been excluded.
\end{abstract}

\section{Introduction}

Dendritic cells (DC) ${ }^{1}$ were first described in the early 1970 s by Steinman et al. In mouse spleen they appear as a distinct type of leukocyte with an extensive network of membranes that express a high density of class II (Ia) antigens (1). They were incapable of any phagocytic functions, even under conditions ( $40 \%$ serum) that normally stimulate phagocytosis in macrophages, but could present soluble antigen such as purified protein derivative (PPD) to $T$ cells, induce $T$ cell proliferation,

Presented at the 1986 and 1987 Annual Meetings of the American Rheumatism Association.

Address reprint requests to Dr. Zvaifler, UCSD Medical Center, 225 Dickinson Street, H-811-G, San Diego, CA 92103.

Received for publication 2 November 1987 and in revised form 29 June 1988.

1. Abbreviations used in this paper: DC, dendritic cells; IFA, immunofluorescence analysis; MLR, mixed lymphocyte reaction; PB, peripheral blood; PLL, poly-L-lysine; PPD, purified protein derivative; SEM, scanning electron microscopy; SFM, synovial fluid mononuclear cell; TEM, transmission electron microscopy.

J. Clin. Invest.

(c) The American Society for Clinical Investigation, Inc.

$0021-9738 / 88 / 11 / 1731 / 15 \$ 2.00$

Volume 82, November 1988, 1731-1745 generate active helper cells from unprimed and memory lymphocytes, and cause B cells to secrete antibodies (2-5). Cultured spleen cells depleted of DC failed to develop anti-TNP cytotoxic $T$ cells while the addition of a small number of DC restored the antigen dependent response (6). Most remarkable, DC are 100 times more potent then any other accessory cells in stimulating $\mathrm{T}$ cells in mixed lymphocyte reactions (MLR) $(7-10)$ and are unique in their ability to stimulate autologous $T$ cells in the absence of antigens (9). This impressive repertoire of immune functions is accomplished by DC in a specific microenvironment. When murine splenic DC and responding $T$ cells are cocultured they aggregate to form distinctive clusters. This occurs during the first $2 \mathrm{~d}$ of a syngeneic mixed leukocyte reaction $(8,11)$. A consequence of the cluster reaction is blastogenesis and the elaboration of IL-2, and B cell helper factors (12) into the syngeneic MLR medium (13). Although the clusters contain $<10 \%$ of the available $T$ cells, these immunocompetent units are responsible for almost all the interleukins and growth factors produced in the cultures $(3,8,14)$ and physical blocking of cluster formation by interposing an artificial membrane abrogates the observed immunological responses (15). In all instances the responsible cell is an Lyt-2- helper T cell $(4,5)$; but murine DC can also cluster with and activate cytotoxic $\mathrm{T}$ cells (16).

DC have been recognized in man, primarily in blood and inflammatory joint effusions $(10,17-21)$ and they are similar to murine DC in their immunologic functions, insofar as they have been studied $(10,22-24)$. However, the cluster phenomenon with human cells has not been analyzed. In this paper we show that DC and $T$ cells from peripheral blood of normal individuals and patients with RA form clusters in syngeneic, allogeneic, and antigenic specific reactions. The clusters contain a centrally located DC and a predictable admixture of CD4 and CD8 lymphocytes and develop morphologic and phenotypic features associated with blastogenesis. Clusters form spontaneously in mononuclear cell populations from RA synovial fluids, but the profile of the participating lymphocytes is different and blastogenesis does not ensue without the addition of specific antigens or synovial fluid. The reasons for the difference in the clusters formed from synovial fluid mononuclear cells as compared to those formed from admixtures of peripheral blood cells is analyzed and their significance discussed.

\section{Methods}

Study population. We studied more than 100 patients with definite or classic RA or other joint diseases. The diagnoses were defined by the clinicians who supplied the synovial fluids that were drawn for therapeutic reasons. Blood samples $(30-100 \mathrm{ml})$ were obtained from some of these same patients and from healthy staff members of our hospital. All subjects gave prior informed consent. 
Synovial fluid mononuclear cell (SFM) isolation. Synovial fluids were obtained by aseptic joint aspiration into heparinized tubes or syringes. SFM were isolated by Ficoll-Hypaque centrifugation, washed three times with RPMI 1640, and cell clumps dispersed by passage several times through a 25 gauge needle. Cell density was adjusted to 1 $\times 10^{6} / \mathrm{ml}$, cultured for $48 \mathrm{~h}$ in $5 \% \mathrm{CO}_{2}, 37^{\circ} \mathrm{C}$ in 100 -mm plastic dishes (Falcon Labware, Cockeysville, MD) in RPMI 1640 supplemented with penicillin $(100 \mathrm{U} / \mathrm{ml})$, streptomycin $(100 \mu \mathrm{g} / \mathrm{ml})$, L-glutamine (2 $\mathrm{mM}$ ) and $10 \%$ FCS or $10 \%$ human AB serum. Before immunofluorescence analysis the cultured SFM were harvested by gentle pipetting, washed free of FCS, and resuspended in RPMI at $2 \times 10^{6} / \mathrm{ml}$.

Immunofluorescence study. For indirect immunofluorescence analysis (IFA), $4 \times 10^{4}$ cells in $20 \mu \mathrm{l}$ of RPMI were attached onto poly-L-lysine (PLL, $50 \mu \mathrm{g} / \mathrm{ml}$; Sigma Chemical Co., St. Louis, MO) coated multi-well slides (Carlson Scientific Inc., Pentone, IL) at $4^{\circ} \mathrm{C}$ for $20 \mathrm{~min}$. All stainings were done at $4^{\circ} \mathrm{C}$ as described elsewhere (21). Briefly, cells were incubated with $20 \mu$ l of the appropriate diluted MAB (see Table I) for $45 \mathrm{~min}$, washed with cold PBS five times, exposed to biotinylated horse anti-mouse IgG for $30 \mathrm{~min}$ and subsequently overlaid with fluorescein conjugated avidin (both from Vector Laboratories, Burlingame, CA) for $30 \mathrm{~min}$. The cells adhering to the PLL slides were then fixed with $3 \%$ formalin and mounted with polyvinyl alcohol (25).

Direct fluorescence analysis was performed using commercially available kits from Becton Dickinson (Mountain View, CA). The "Simultest" anti-Leu 3 FITC plus anti-Leu 2a PE was used to determine the CD4 (phycoerythrin conjugated T4) and CD8 (fluorescein conjugated T8) T cell ratio. The Simultest anti-Leu 7 FITC plus anti-Leu 2a PE was used to determine cells expressing simultaneously both NK and suppressor/cytotoxic markers.

Data analysis of immunofluorescence study. PLL adherent cells bearing the appropriate fluorescent Abs were viewed using a Zeiss fluorescence microscope equipped with the epifluorescence condenser III RS. 500 mononuclear cells were counted. The anti-DQ monoclonal antibodies $8 \mathrm{C} 4$ and/or Leu 10 were used to mark DC and gave identical results. The total DC and the percent of DC present in cluster was determined by counting only the DQ positive cells with a dendritic appearance (21), and those DC that were associated with lymphocytes, respectively. A cluster was defined as an aggregation of cells that forms spontaneously in a 48-h culture with a centrally located DC holding five or more lymphoid cells within its long dendritic processes (see Fig.
1). The $T 4 / T 8$ ratio in a cluster was determined by first counting the total number of lymphocytes in a cluster and then determining the percent of fluorescent T4 cells with a rhodamine filter and the percent of fluorescent T8 cells with fluorescein filter. The MAb anti-Leu 7 was used to identify the NK cell population in both the clusters and background. Two-color flow cytometric analysis with MAbs from a simultest (see above) gave us the percentage of a unique cell population in the SFM that bore both the NK and suppressor/cytotoxic markers. The same cells in the clusters were determined visually by fluorescence microscopy with a procedure similar to that used for the T4/T8 ratio. Data from cluster analysis was obtained by evaluating all the clusters found in each well of the PLL coated slide.

Electron microscopy. SFM, from 48-h cultures, were adhered onto PLL coated Nalgene polymethyl pentene (PMP) $100 \times 20 \mathrm{~mm}$ Petri dishes or PLL-coated circular cover slips (12 mm, Fisher Scientific, Pittsburgh, PA) for $20 \mathrm{~min}$ at room temperature. The cells were fixed at room temperature in a fresh mixture of $2 \%$ gluteraldehyde (Electron Microscopy Sciences, Fort Washington, PA), RPMI 1640, $20 \mathrm{mM}$ Hepes (Gibco Laboratories, Grand Island, NY), pH 7.4 for $1 \mathrm{~h}$, rinsed with PBS and postfixed with $1 \%$ osmium tetroxide for $1 \mathrm{~h}$ on ice. Cells on PMP dishes were embedded in EPON812 (EMS) for transmission electron microscopy (TEM) analysis. Cells on the circular coverslips were processed for scanning electron microscopy (SEM) studies. An EM 300 (Philips Electronic Instruments, Inc., Mahwah, NJ) was used for the TEM and a Hitachi S405A was used for the SEM.

Mixed leukocyte reactions. SFM or PBM obtained by Ficoll-Hypaque $(F H)$ density gradient centrifugation were subsequently separated into non- $T$ and $T$ fractions by two methods; either aminoethylisothiouronium (AET)-SRBC rosetting (26), or the T and non-T cells were separated by nylon wool columns (27) and Nycodenz monocyte gradients (28) (Nyegaard, Oslo, Norway), respectively. Both fractions were plated onto Falcon plastic dishes for $2 \mathrm{~h}$ to facilitate monocytes adherence. A DC-enriched population was obtained by gently removing the nonadherent fraction from plates containing the non-T cells. Purified T cells came from the nonadherent AET-SRBC positive population or the nonadherent nylon wool eluted population. To insure that the MLRs were not an artifact generated by exposure to FCS or sheep red cell xenoantigens the FH separated PBM were washed, resuspended with $10 \%$ pooled inactivated human AB serum (Pel-Freez Biological, Brown Deer, WI) RPMI, and plated onto plastic dishes for $2 \mathrm{~h}$ at $37^{\circ} \mathrm{C}$ in a $5 \% \mathrm{CO}_{2}$ environment. Afterward, the nonadherent popu-

Table I. Monoclonal Mouse Anti-human Leukocyte Antibodies

\begin{tabular}{|c|c|c|c|c|}
\hline Name & $\begin{array}{c}\text { Molecular } \\
\text { weight }\end{array}$ & $\begin{array}{l}\text { IgG } \\
\text { subclass }\end{array}$ & Source & Specificity \\
\hline \multicolumn{5}{|c|}{$K D$} \\
\hline $8 \mathrm{C} 4$ & ND & IgM & $\begin{array}{l}\text { R. M. Steinman, The Rockefeller University, } \\
\text { New York, NY }\end{array}$ & HLA-DQ \\
\hline Leu 10 & 27,32 & $\operatorname{IgG}_{1}$ & Becton-Dickinson \& Co. & HLA-DQ \\
\hline $\mathbf{I}_{2}$ & $29-34$ & $\operatorname{IgG}_{2 \mathrm{a}}$ & Coulter Immunology & HLA-DR \\
\hline KiM1 & & IgM & A. J. Radzun, Christian Albrecht University & Monocytes and ID cells \\
\hline OKMI & 155 & $\mathrm{IgG}_{2 \mathrm{~b}}$ & Ortho Diagnostic Systems, Inc. & C3bi receptors \\
\hline 63D3 & 200 & $\mathrm{IgG}_{1}$ & Bethesda Research Laboratories & Monocytes \\
\hline HB5 & 145 & Ascites & D. D. Fearon, Harvard University & Anti-CR2 \\
\hline Leu 7 & 110 & IgM & Becton Dickinson & NK cells subset $\&$ T cells \\
\hline Leu $11 b$ & $50-70$ & IgM & Becton Dickinson & Fc IgG receptor on NK cells and neutrophil \\
\hline OKT9 & 180 & $\operatorname{lgG}_{1}$ & Ortho Diagnostic Systems & Transferrin receptors \& $100 \%$ lymphoblasts \\
\hline Tac & $50-60$ & Ascites & T. A. Waldmann, NIH, Bethesda, MD & IL-2 receptor \\
\hline Leu $18(2 \mathrm{H} 4)$ & 220 & $\operatorname{IgG}_{1}$ & Becton Dickinson & $\begin{array}{l}\text { T suppressor/inducer subsets, NK cells and } \\
\text { B cells }\end{array}$ \\
\hline 4B4 & 135 & $\operatorname{IgG}_{1}$ & Coulter Immunology & $\begin{array}{l}\text { T helper/inducer subsets, null cells and } \\
\text { monocytes, B cells }\end{array}$ \\
\hline
\end{tabular}


Table II. IFA Analysis of Synovial Fluid DC Forming Clusters at $48 \mathrm{~h}$

\begin{tabular}{lccc}
\hline \multicolumn{1}{c}{ Patients } & No. & $\% \mathrm{DC}^{*}$ & $\%$ in Clusters \\
\hline RA variant & $(1)$ & 5 & 0 \\
Chronic knee infection & $(1)$ & 3 & 0 \\
Reiter's & $(4)$ & $10.33 \pm 0.57$ & 0 \\
Psoriasis & $(6)$ & $8.80 \pm 2.13$ & $4.30 \pm 4.50$ \\
Gout & $(1)$ & 2 & 0 \\
Undefined synovitis & $(2)$ & 1.5 & 0 \\
RA & $(54)$ & $6.52 \pm 3.27$ & $61.30 \pm 19.84$ \\
JRA & $(3)$ & $8.30 \pm 2.10$ & $62.30 \pm 22.00$ \\
& & & \\
\hline
\end{tabular}

No. Number of patients.

* Cells positive for the 8C4MAb and exhibiting DC morphology.

${ }^{\ddagger}$ Percent DC that had five or more T cells surrounding each DC.

lation was removed by gently swirling the plates and aspirating with a pipette and was layered over Nycodenz. After centrifugation at room temperature for $12 \mathrm{~min}$ at $600 \mathrm{~g}$ the lymphocytes that pelleted to the bottom (99\% T cells) were harvested and washed twice with medium and $10 \%$ AB serum. The PBM remaining in the plastic dish were washed three to five times more until no nonadherent cells could be seen when examined with an inverted microscope. Then fresh medium with $10 \% \mathrm{AB}$ serum was added to the plates and they were recultured for an additional $2 \mathrm{~h}$. The cells released during this second culture period were obtained by gentle pipetting and aspiration of the plates with medium.

Using these methods we obtained the following yields: $T$ cells prepared from PBM by rosetting and nylon wool were $80-95 \%$ pure. Those obtained by Nycodenz centrifugation always exceeded $95 \%$ pu- rity. The T cells from SFM were stickier and usually contained contaminating DCs (2-5\%). The DC in the non-T from blood were generally $40-60 \%$ pure, occasionally better yields were obtained with the Nycodenz procedure. DC were easier to isolate from SFM because of the larger starting numbers and $60-80 \%$ purity was the rule.

Enriched populations of DC and T cells from synovial fluids or from peripheral blood were cultured together in autologous and allogeneic mixtures in RPMI 1640 supplemented with penicillin $(100 \mathrm{U} / \mathrm{ml})$, streptomycin $(100 \mu \mathrm{g} / \mathrm{ml})$, and L-glutamine $(2 \mathrm{mM})$ with either $10 \%$ heat inactivated FCS or $10 \%$ pooled human AB serum. The DC:T ratio was $1: 5$ to $1: 10.1 \mathrm{ml}$ of the mixture at a density of $2 \times 10^{6}$ cells $/ \mathrm{ml}$ was cultured in 24 well flat bottomed tissue culture plates (Linbro Laboratories, Hamden, CT). At appropriate time points, the cells and medium were gently resuspended and $0.2 \mathrm{ml}$ of the culture was transferred to 96 multi-well flat bottomed plates and $\left[{ }^{3} \mathrm{H}\right] \mathrm{TdR}(0.1 \mu \mathrm{Ci})$ was added to each well $18 \mathrm{~h}$ before harvesting with a semiautomated multiple sample harvester (Otto Hiller, Madison, WI) with glass fiber filters in triplicates. Filters were resuspended in scintillation fluid for counting in a beta scintillation counter (Beckman LS-230; Beckman Instruments, Inc., Palo Alto, CA). In some AMLR experiments, mitomycin $\mathrm{C}$ (Sigma Chemical Co.) at $25 \mu \mathrm{g} / \mathrm{ml} 5 \times 10^{6}$ cells $\left(60 \mathrm{~min}\right.$ at $37^{\circ} \mathrm{C}$ ) was used to treat enriched DC populations. Results from the $\left[{ }^{3} \mathrm{H}\right] \mathrm{TdR}$ experiments were expressed as the difference between the DC plus $T$ proliferation minus the $\mathrm{T}$ proliferation alone. Proliferation in the DCenriched population was always minimal. Thymidine incorporation in allo-MLR was $\left.35,000 \pm 2,700 \mathrm{cpm} \mathrm{[}{ }^{3} \mathrm{H}\right] \mathrm{TdR}$ in four experiments. The mean $\left[{ }^{3} \mathrm{H}\right] \mathrm{TdR}$ incorporation for auto-MLR done with FCS was $22,000 \pm 12,000 \mathrm{cpm}$ (eight experiments); and 5,024 $\pm 1,834 \mathrm{cpm}$ in three studies where xenoantigen exposure was avoided.

On each day of harvest, additional samples were also taken out for phase contrast and fluorescence microscopy analysis using various MAbs staining on PLL-coated slides (see above). In MLR employing mixtures of cells from SF and blood there was sometimes an admixture of DC from the two sources. This occurred most often in the combina-

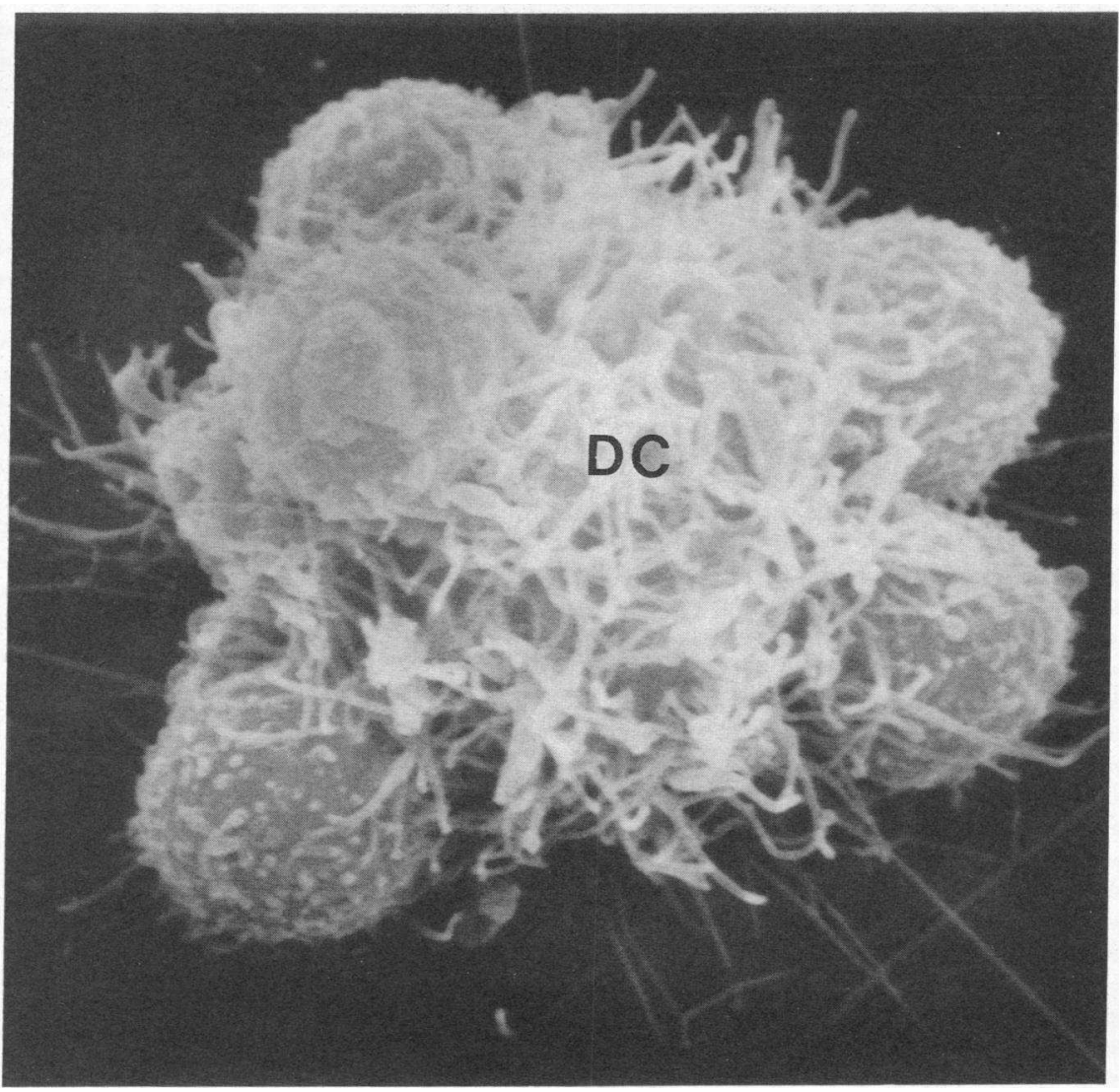

Figure 1. SEM of a cluster taken from cultured rheumatoid arthritis synovial fluid mononuclear cells at $\mathbf{4 8} \mathrm{h}$. A centrally located $D C$ is embracing a various number of $T$ cells with its long dendritic process $(\times 5,000)$. 


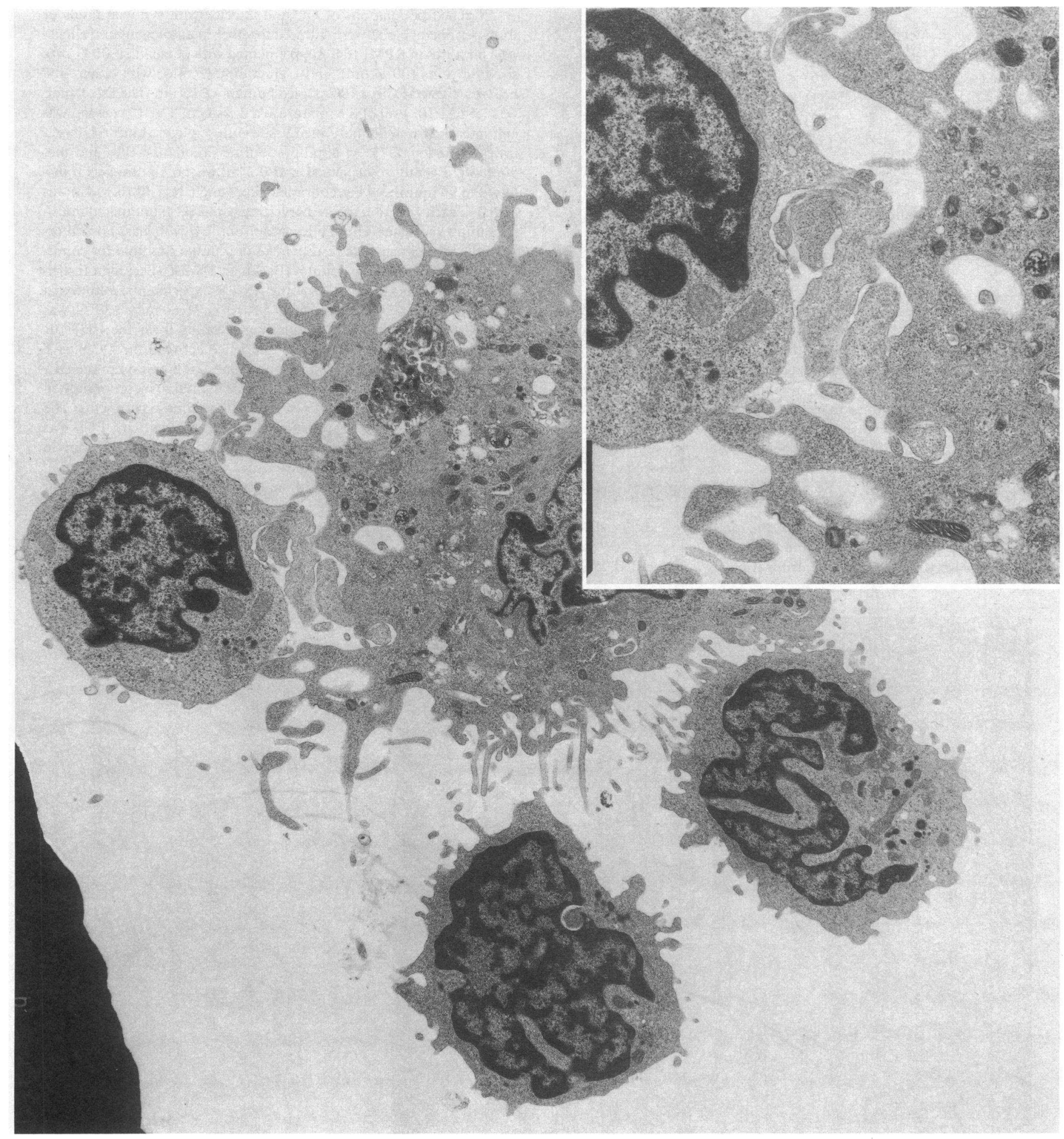


Table III. Phenotype of SFM Cells from Patients with Inflammatory Synovitis

\begin{tabular}{lcccccccc}
\hline & \multicolumn{8}{c}{ Monoclonal antibodies* $^{*}$} \\
\cline { 2 - 7 } & T11 & 63D3 & B1 & Leu 7 & Leu 11b & Tac & SC2 & 8C4 \\
\hline RA (20) & $71 \pm 7$ & $19 \pm 8$ & $4 \pm 2$ & $19 \pm 8$ & $6 \pm 4$ & $15 \pm 5$ & $40 \pm 13$ \\
Non-RA $(10)^{\ddagger}$ & $65 \pm 12$ & $23 \pm 6$ & $5 \pm 4$ & $15 \pm 10$ & $14 \pm 10$ & $19 \pm 13$ & $45 \pm 21$ & $9 \pm 4$ \\
\hline
\end{tabular}

* T11, sheep erythrocyte receptor; 63D3, macrophages/monocytes; B1, B lymphocytes; Leu 7 and Leu 11b, NK cells; Tac, IL-2 receptor; SC2, anti HLA-DR; 8C4, anti HLA-DQ. Indirect fluorescence microscopy was used to determine percent positive. " Includes Reiter's (3); psoriatic (3); chronic monoarticular synovitis (3); gouty arthritis (1).

tion of PB DC with SF T cells. However, SF DC can be distinguished by their size and morphology and clusters containing $D C$ with this appearance (seldom $>5 \%$ of the total) were excluded from analysis.

Activation of RA SFM by cytokines. Recombinant gamma interferon (rIFN-gamma) was a gift from AmGen Biologicals (Thousand Oaks, CA), purified natural interleukin (IL-1) was purchased from Cistron Technology (Pine Brook, NJ), and rIL-2 was provided by Cetus Corp. (Emeryville, CA). rIFN-gamma (50 U/ml), IL-1 $(5 \mathrm{U} / \mathrm{ml})$, IL-2 $(40 \mathrm{U} / \mathrm{ml})$ or $5-10 \%$ autologous or allogeneic SF was added to SFM either at the initiation of the cultures or after $48 \mathrm{~h}$. Controls were SFM cultured for $96 \mathrm{~h}$ in RPMI and an additional 5 or $10 \%$ FCS adjusted to match the percentage of SF added in the experiments.

\section{Results}

Dendritic cells in blood and inflammatory synovial effusions. Mononuclear cells (SFM) isolated from the synovial fluids of more than 100 patients with various forms of acute and chronic inflammatory arthritis were studied. A majority of the samples came from patients diagnosed as having RA. DC constituted from 2 to $10 \%$ of the SFM population in both RA and inflammatory non-RA joint fluids. There was little difference in the DC from either source when examined by phase contrast microscopy or by immunofluorescence microscopy for surface antigens (see below). On the other hand, DC identified in peripheral blood (PB) are morphologically different from their counterparts in synovial fluid. Blood DC are smaller, have fewer and shorter dendritic processes, and constitute $\sim 1.0 \%$ of the total circulating mononuclear cell population. Their phenotype was similar to that of SF DC and both blood DC and SF DC form clusters spontaneously when cultured in vitro at $37^{\circ} \mathrm{C}$ with autologous or allogeneic $\mathrm{T}$ lymphocytes.

Cluster formation in cultures of mononuclear cells from inflammatory synovial effusions is unique to $R A$. When SFM were observed after $48 \mathrm{~h}$ of in vitro culture, the cells from RA patients demonstrated collections of lymphoid cells adhering to a centrally located DC (Table II). A scanning electron micrograph of a typical cluster seen after RA SFM were cultured for $48 \mathrm{~h}$ reveals a centrally located DC embracing various numbers of lymphocytes within long dendritic cytoplasmic processes (Fig. 1). Transmission electron microscopy showed evidence of increased surface interactions between a DC and the surrounding lymphocytes (Fig. 2). The number of $\mathrm{T}$ cells in the cluster was variable, ranging from 3 to 10 per DC. The majority of the clusters had five to six lymphocytes per DC.
Knowing the number of mononuclear cells present at the start of the culture $\left(3.97 \pm 1.2 \times 10^{6} / \mathrm{ml}\right.$ in 10 patients $)$, the percentage of DC $(4.9 \pm 2.6 \%)$ and the number of clusters per $\mathrm{ml}$ SFM observed in a hemocytometer $\left(0.16 \pm 0.11 \times 10^{6} / \mathrm{ml}\right)$ it can be calculated that $4 \times 10^{4}$ clusters form per starting $10^{6} \mathrm{SFM}$, and that the clusters contain considerably $>50 \%$ of the DC in SFM and $5-8 \%$ of the available $\mathrm{T}$ lymphocytes.

Cluster reactions were not seen in fluids from any other form of chronic inflammatory arthritis. This was surprising because DC constituted a greater percentage of the total SFM in patients with psoriatic arthritis or Reiter's syndrome. In these conditions one or two lymphocytes were occasionally in contact with the DC's, but typical clusters were not seen. The phenotype of the SFM in the two groups was the same and there was an adequate representation of potentially reactive $T$ cells (Table III). The difference in cluster formation could not be explained by treatment, because although the RA patients were given many different drugs and combinations of drugs, several individuals were studied before treatment was started. Also many of the patients with chronic inflammatory non-RA joint diseases were taking similar medications. At this time, there is no explanation for the observed difference in cluster formation between the two groups.

Phenotype of the cells in a cluster. Various monoclonal antibodies were used to analyze the SFM and the constituents of the clusters. All types of mononuclear cells were present in the synovial fluid; in contrast only cells that were reactive with monoclonal antibodies to $\mathrm{T}$ cells and NK cells were detected in the clusters. While varying numbers of $T$ lymphocyte activation markers were present in the background $T$ cells, the clustered $T$ cells were devoid of Ia, the IL-2 receptor (Tac), VLA-1, and transferrin receptor (T9) (Table IV). Employing two-color direct immunofluorescence microscopy, the $\mathrm{T}$ cells in individual clusters were observed to be both CD4 and CD8. CD8 cells predominated, so the $\mathrm{T} 4 / \mathrm{T} 8$ ratio in the clusters was $0.71 \pm 0.39$. In almost every instance there were significantly more CD4 cells in the lymphocytes comprising the starting SFM population $(\mathrm{T} 4 / \mathrm{T} 8$ ratio $=1.26 \pm 0.60)$. Variable numbers of cells with an NK phenotype were the only other mononuclear cell present in the clusters. $0-10 \%$ of the cells in clusters stained with the MAb Leu 11b. When the Leu 7 MAb was used, which detects a cell surface antigen expressed on some NK cells, $20-50 \%$ of the clustered lymphocytes were positive. Their numbers in the clusters did not correlate with the Leu

Figure 2. Transmission electron micrograph of a cluster taken from cultured rheumatoid arthritis synovial fluid mononuclear cells at $48 \mathrm{~h}$. Note (inset) the increased surface interactions between DC and T cells, specialized cell junctions between DC and T cells were not found $(\times 3,300$, inset $\times 17,900)$. 
Table IV. Phenotype of SFM Cells and Clustered T Cells

\begin{tabular}{|c|c|c|c|}
\hline \multirow[b]{2}{*}{ Cell type } & \multirow[b]{2}{*}{ MAbs } & \multicolumn{2}{|c|}{$\begin{array}{l}\text { Presence or } \\
\text { absence in: }\end{array}$} \\
\hline & & Clusters & SFM \\
\hline \multirow[t]{4}{*}{$\mathrm{T}$ cells } & $\mathrm{T} 3$ & + & + \\
\hline & T4 (helper/inducer) & + & + \\
\hline & T8 (suppressor/cytotoxic) & + & + \\
\hline & $\begin{array}{l}\text { T11 (E-rosette receptor } \\
\text { associated) }\end{array}$ & + & + \\
\hline NK & $\begin{array}{r}\text { Leu } 7 \text {, Leu } 11 \mathrm{~b} \text { (Fc IgG } \\
\text { receptor on NK cells) }\end{array}$ & + & + \\
\hline B cells & B1, B2, B7 & 0 & + \\
\hline Monocyte/macrophage & $63 \mathrm{D} 3,3 \mathrm{C} 10$ & 0 & + \\
\hline $\mathbf{T}$ cell activation markers & & Clusters & SFM \\
\hline Ia & $\begin{array}{l}\text { SC2 (HLA-DR) and 8C4 } \\
\text { (DQ) }\end{array}$ & 0 & + \\
\hline IL-2 receptor & Tac & 0 & + \\
\hline VLA & $\mathrm{A}-1 \mathrm{~A} 5, \mathrm{TS} 2 / 7,12 \mathrm{~F} 1$ & 0 & + \\
\hline $\begin{array}{l}\text { Transferrin/ } \\
\text { Lymphoblasts }\end{array}$ & T9 & 0 & + \\
\hline
\end{tabular}

$7 / 11$ b representation in the starting SFM population where they constituted $\sim 20 \%$ of the total. Furthermore, most Leu-7 bearing cells in the clusters simultaneously displayed the CD8 antigen. This was suspected initially when the total of NK and $T$ cells exceeded $100 \%$ and was confirmed using simultaneously a phycoerythrin labeled anti-Leu 7 and fluoresceinated anti-T8 antibody.

The phenotype of synovial fluid DC has been analyzed in detail and reported elsewhere $(21,24)$. They are rich in surface class I and class II glycoproteins (Ia, HLA-DR, and DQ) and show light staining of the $155,000-D$ component of the $\mathrm{iC} 3 \mathrm{~b}$ receptor (CR3), as demonstrated with MAb OKM1. An irregular, infrequent dim fluorescence was observed on some DC with HB-5, a MAb that reacts with an epitope on the CR2 receptor; however, no reactivity was seen with the MAb B-7, which recognizes the EBV receptor within the CR2 complex. $\mathrm{Ki}-\mathrm{M} 1$, an antibody reported to identify the interdigitating cells in the $T$ cell rich area of lymph nodes, stained both synovial fluid macrophages and DC. This antibody appears to be directed against the p150,95 leukocyte functional antigen. As noted above, the clusters were analyzed with Tac (IL-2 receptor) and T9 (transferrin receptor) and neither the lymphocytes nor DC stained at $48 \mathrm{~h}$. However, these antigens were seen on DC-activated by cytokines or obtained from mixed leukocyte cultures after $96 \mathrm{~h}$ (see below).

Seven day kinetics of RA SFM clusters. The kinetics of cluster formation and disassembly was studied by culturing RA SFM for $7 \mathrm{~d}$ and examining the cluster profile at 48,96 , and $168 \mathrm{~h}$. Early in the culture the lymphocytes clustered about DCs and reached a maximal size by $48 \mathrm{~h}$. Thereafter, the lymphocytes in the clusters disengaged leading to a reduction in the number of clusters, but not the total number of DC in the culture. This was taken as evidence of the viability of DC in culture and speaks against any cytotoxicity directed at DC. During this period there was no significant change in the num- ber of T4, T8, or Leu 7 positive cells in the cultures, but their proportions in the clusters were modified slightly with the passage of time. Between 72 and $96 \mathrm{~h}$, the percentage of DCs in clusters was reduced from $50-60 \%$ to $25-30 \%$ and by $168 \mathrm{~h}$, only $20 \%$ of the DC existed in clusters. The ratio of T4/T8 in the background remained essentially unchanged throughout the entire 7-d culture. Overall, the number of $T$ cells within the clusters fell. The loss was primarily in the CD8 population resulting in an apparent increase in the T4/T8 ratio (2.0 at 168 h). The SFM clusters remained inert throughout the $7 \mathrm{~d}$ without a change in $\mathrm{T}$ cell morphology or phenotype in the clusters as assessed by phase and immunofluorescence microscopy. Consistent with these observations, there was no proliferation detected by $\left[{ }^{3} \mathrm{H}\right] \mathrm{TdR}$ uptake experiments at the end of the culture period (results not shown).

Characteristics of clusters formed in mixed leukocyte reactions. The observation that the T4/T8 ratio in the RA synovial fluid clusters did not reflect the make-up of the SF T cells and the inert (nonprogressive) nature of the clusters raised a number of questions. Are CD8 cells the predominant lymphocyte in any immunologic reaction involving human DC? Is the quiescent (nonprogressive) nature of the clusters a characteristic of all human DC-lymphocyte interactions? These questions were addressed by analyzing the phenotype and kinetics of clusters which formed in autologous and allogeneic mixtures of PBM. Initially, isolated PBM were cultured for $48 \mathrm{~h}$ under conditions identical to those used in the synovial fluid studies. Approximately $0.5-1 \%$ of the PBM were Ia rich cells with a distinctive morphology similar to the synovial fluid dendritic cells. The peripheral blood cells formed clusters of four to six cells about a central DC with autologous lymphocytes. The predominant lymphocyte within the cluster is a CD4 cell, with a T4/T8 ratio of 5.7 (Table V). After $72 \mathrm{~h}$, individual T cells within the clusters become elongated, enlarged, and acquired cell surface Tac and/or T9 antigen. At $6 \mathrm{~d}$, most of the blasts, mainly T4 staining cells, are seen in the background outside the clusters (Fig. 3). Very similar results were obtained using isolated autologous $\mathrm{T}$ and non- $\mathrm{T}$ cell populations enriched for DC. To exclude a role for SRBC or calf serum xenoantigens the $T$ cells and non- $T$ population enriched for $D C$ from the same individual were isolated by gradient centrifugation and cultured together in human AB serum (see Methods). Thymidine incorporation on the fifth day was $5,024 \pm 1,834 \mathrm{cpm}$ in three experiments with cells from normal individuals. The T4/T8 ratio (4.5) in the cluster, the appearance of Tac and T9 on the clustered lymphocytes and the phenotype of the cells in the background were all similar to those observed in cultures containing FCS. The difference between the auto-MLR done in the presence or absence of xenoantigens can be seen in the proliferation assay. The presence of xenoantigen induced a threefold increase of $\left[{ }^{3} \mathrm{H}\right] \mathrm{TdR}$ uptake over those done without xenoantigens such as FCS and SRBC. This is in agreement with the observation that $\sim 20 \%$ of the $\mathrm{T}$ cells are Tac and T9 reactive by 7 days with FCS and with $\mathrm{AB}$ serum, $\sim 5 \%$ of the $\mathrm{T}$ cells are $\mathrm{T} 9$ positive by day seven.

Allogeneic MLR are similar to autologous MLR, except that the clusters contain larger numbers of lymphocytes (average 7-8 per cluster), the lymphocytes appear more tightly bound to the central DC and at $72 \mathrm{~h}$ almost all the $T$ cells are CD4 (Table V). In addition, the clusters develop slower in the allogeneic mixtures and the percentage of $T$ cells which become activated and form blasts is greater, consistent with the 
Table V. T4/T8 Ratio and Leu 7+ Cell Numbers in Clusters Taken from 48-h Cultures of SFM, $P B D C+$ Autologous $P B T$ and PBDC + Allogeneic PBT

\begin{tabular}{|c|c|c|c|c|c|c|}
\hline & \multicolumn{3}{|c|}{ Clusters* } & \multicolumn{3}{|c|}{ Background $^{\ddagger}$} \\
\hline & $\mathrm{SFM}^{8}$ & Auto-MLR & Allo-MLR' & SFM & Auto-MLR & Allo-MLR \\
\hline T4:T8 & $0.71 \pm 0.39$ & $5.70 \pm 1.5$ & 70.0 & $1.26 \pm 0.60$ & $3.04 \pm 1.0$ & $3.88 \pm 2.5$ \\
\hline \%Leu 7" & $29.70 \pm 13.92$ & $2.25 \pm 2.8$ & $8 \pm 3$ & $21.60 \pm 9.35$ & $13.18 \pm 5.9$ & $16.00 \pm 9.0$ \\
\hline
\end{tabular}

* The ratio of T4:T8 $\mathrm{T}$ cells in the clusters and the percent $\mathrm{T}$ cells in the clusters that were Leu 7+. ${ }^{\ddagger} \mathrm{The}$ ratio of T4:T8 and percent Leu 7 cells that were outside of the clusters. $\$$ T4:T8 - SFM from 20 individuals; auto-MLR from five individuals and allo-MLR from three individuals. " Percent Leu 7 based on 10 individuals.

greater thymidine incorporation, and the majority of proliferating cells in the background were CD4. Initially, CD8 cells were not seen in the clusters, but their numbers increased over time so that the T4/T8 ratio was $\sim 3$ at the end of $7 \mathrm{~d}$. Leu 7 staining cells were always infrequent. During the maturation of the clusters, between the 48th and 96th $\mathrm{h}$, a small percentage of the DC were seen to acquire cell surface IL- 2 and transferrin receptors. These results indicate that the clusters formed from PB DC and T cells are immunoreactive units and the $T$ cells in these clusters are capable of undergoing morphological and phenotypic changes associated with blastogenesis and these changes correlate with the increase of proliferations by $\left[{ }^{3} \mathrm{H}\right]-$ TdR uptake at $168 \mathrm{~h}$.

Testing the immunocompetence of $R A T$ cells and DC. To exclude the possibility that RA synovial fluid $T$ cells are unresponsive or that RA synovial fluid DC are ineffective stimulators, $T$ cells isolated from the blood of normal individuals or RA patients were mixed with enriched SF DC populations. The mixed leukocyte reactions were either autologous or allogeneic. As can be seen in Table VI, the $\mathrm{T} 4 / \mathrm{T} 8$ ratios $(2.10 \pm 1.12$ for auto-MLR and $3.46 \pm 1.65$ for allo-MLR) were somewhat less than observed in normal cell mixtures (Table $\mathrm{V}$ ), but the $\mathrm{T}$ cells in the clusters which formed were capable of undergoing activation and blastogenesis in 48 to $72 \mathrm{~h}$, and the SF DC developed surface staining with anti-Tac or anti-T9 (Fig. 4). Essentially the same results were obtained in the reverse situation when isolated $R A$ synovial fluid $T$ cells were cocultured with autologous or allogeneic blood DC (Table VI). The SFT were activatable by PBDC. Because the mixing experiments required coculture of isolated $\mathrm{T}$ and $\mathrm{DC}$ enriched non-T fractions, it was necessary to determine whether synovial fluid cells handled in a similar manner would respond differently than unseparated mixtures. No such difference was observed; the cluster profiles and T4/T8 ratios of isolated RA SF T cells cocultured with DC enriched SF non-T cell fractions were similar to unseparated SFM.

An additional opportunity to test the immunocompetence of synovial fluid DC was provided by a patient with the recent reactivation of tuberculosis and joint effusions due to active RA. The clusters that formed from SFM at $48 \mathrm{~h}$ in the absence of antigen were similar to other RA clusters with a T4/T8 ratio of 0.83 . Over the next $96 \mathrm{~h}$ the $\mathrm{T}$ cells in the clusters showed no evidence of progression to an activated state. In contrast (Fig. 5) when PPD was added to his SFM culture the clusters formed were larger at $48 \mathrm{~h}$ and $53 \%$ of the clusters at that time contained blastic cells of the CD4 phenotype. This did not reflect activity of a separate set of DC, since every available DC in the culture reacted in the same way with lymphocytes. No activation was seen if PPD was added to cultures of RA SFM from two nonsensitized individuals; the cluster $\mathrm{T} 4 / \mathrm{T} 8$ ratio at $48 \mathrm{~h}$ was identical to the others; i.e., about 0.70 (results not shown).

A variety of cytokines were added individually and in combinations to the SFM cultures. Neither IL-1, IL-2, nor IFNgamma introduced at the initiation of the culture or after cells had been in culture for $48 \mathrm{~h}$ caused any morphologic or phenotypic change in the $T$ cells, although occasionally the DC developed surface staining with anti-T9 or anti-Tac. However, if 5-10\% autologous or allogeneic synovial fluid was added to the SFM cultures at $48 \mathrm{~h}$, after the appearance of clusters, activation and blastogenesis of CD4 occurred in 5\% of the clusters. If a higher percentage of SF was added at the initiation of the cultures, however, clusters formed poorly and remained inert. Experiments are in progress to further dissect this significant observation.

\section{Discussion}

Cells analogous to the DC of rodents are found in human blood and synovial effusions $(10,17,18,20,21)$, but heretofore the clustering between human DC and T lymphocytes has not been analyzed. Almost all the available DC in cultured peripheral blood form clusters at 24 to $48 \mathrm{~h}$. These clusters contain a central DC embracing 6 to 10 lymphocytes; twothirds or more are CD4-bearing cells, the remainder are CD8+. Cells with NK markers are infrequent. Over the ensuing 48 to $72 \mathrm{~h}$ the CD4 cells enlarge and acquire membrane transferrin receptor. Subsequently, many of the cells in a cluster show morphologic features of blast transformation and activation; at this time similar appearing cells can be demonstrated in the background. After $7 \mathrm{~d}$ of culture, the $\mathrm{T}$ cells remaining in the cluster are smaller and occasional Leu $7+/$ NK cells are identified. In auto-MLR experiments using populations enriched for autologous DC and T cells an identical sequence was observed. Furthermore, this was not an artifact induced by xenoantigens; since experiments employing $T$ cells and DC, which were not exposed to sheep cells or fetal calf serum gave similar results (see Results).

In allogeneic reactions, the clusters form slower, reaching a maximum size after $72 \mathrm{~h}$, and contain larger numbers of lymphocytes. Surprisingly, almost all are CD4 suggesting that the expansion of CD8 CTL, a feature of allogeneic responses, occurs via soluble mediators (work in progress) as suggested by others $(29,30)$. The subsequent blast transformation and $\mathrm{T}$ cell 

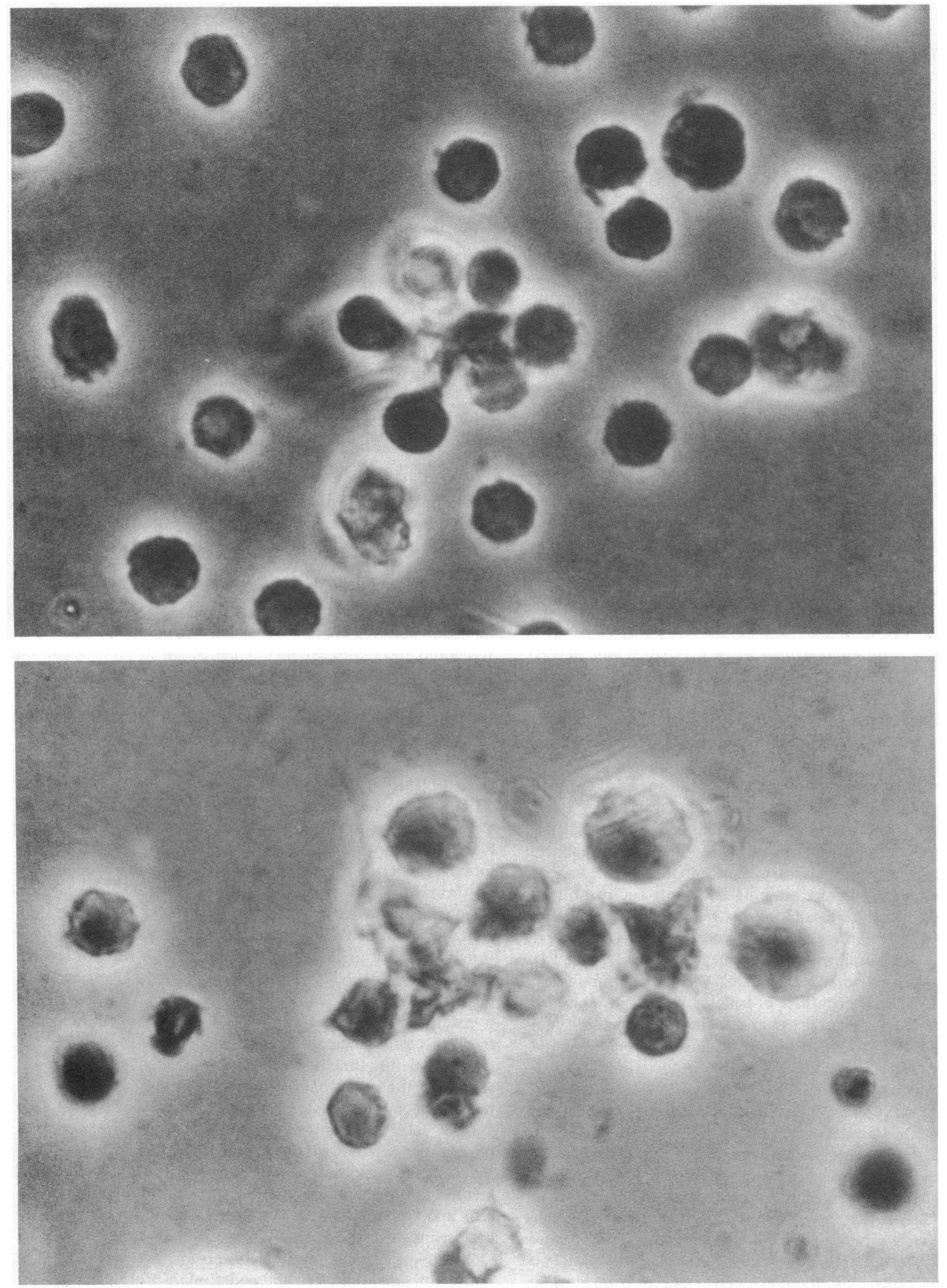

Figure 3. Phase contrast micrographs at four different timepoints in an auto-MLR with peripheral blood mononuclear cells. Clusters appear at $48 \mathrm{~h}$ and are looser than seen with synovial fluid DC (upper left); at $72 \mathrm{~h}$, blasts were detected in some of the clusters (upper

right); by $96 \mathrm{~h}$ many of the CD4 cells in the clusters were blasts (lower left). At $168 \mathrm{~h}$, the majority of the blasts were seen outside of the clusters in the background (lower right). 

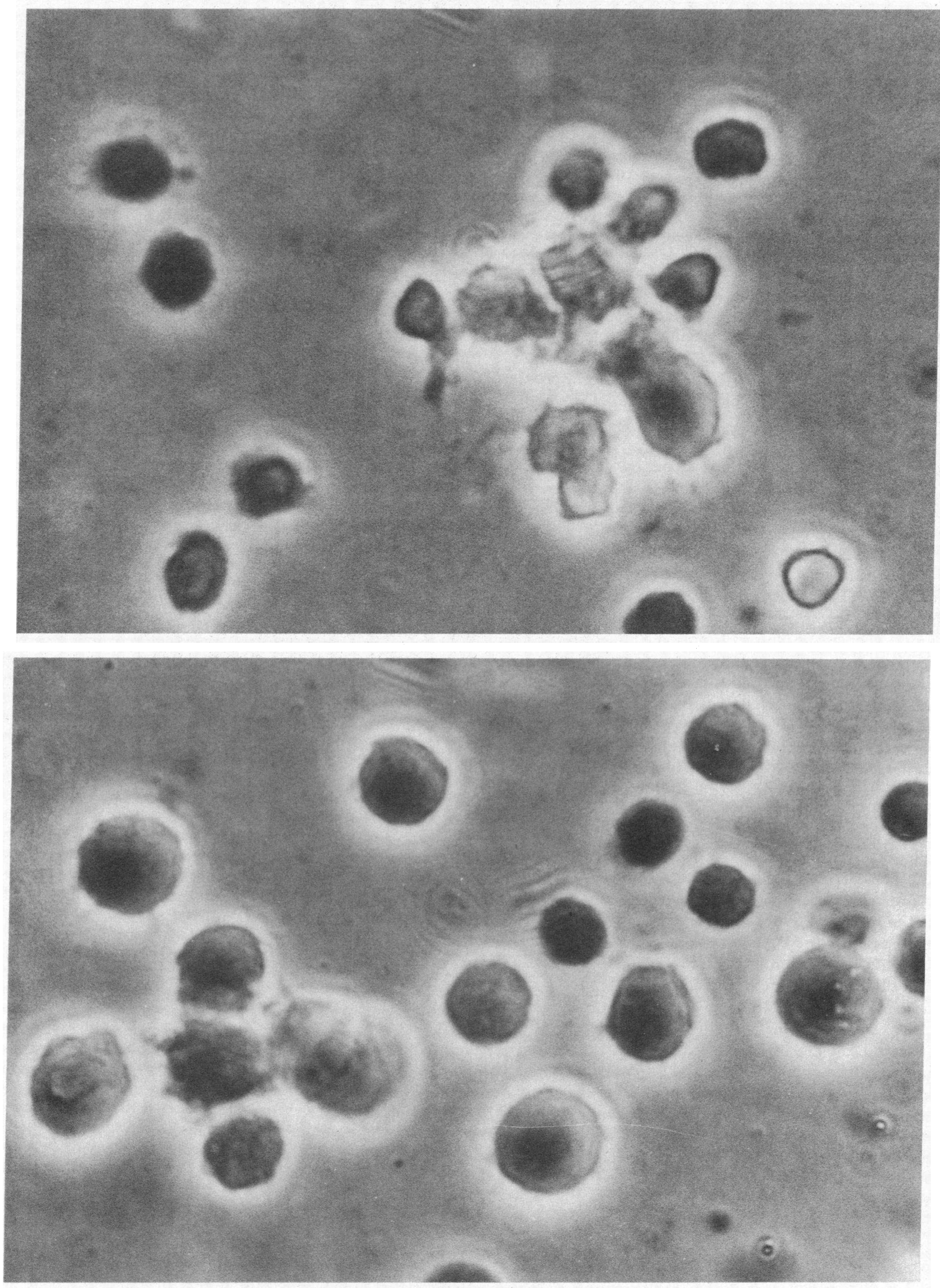

Figure 3 (Continued) 
Table VI. SF DC Are Capable of Stimulating T Cells

\begin{tabular}{|c|c|c|c|c|c|}
\hline Cell type & Background $\mathrm{T} 4 / \mathrm{T} 8^{*}$ & Cluster T4/T8** & Blasts/T9+ & $N$ & $P$ \\
\hline SF DC + auto SFT & $1.26 \pm 0.60$ & $0.71 \pm 0.39$ & - & 20 & $<0.001$ \\
\hline SF DC + auto PBT & $2.40 \pm 0.79$ & $2.10 \pm 1.12$ & + & 5 & NS \\
\hline SF DC + allo PBT & $2.39 \pm 0.87$ & $3.46 \pm 1.65$ & + & 10 & $<0.05$ \\
\hline PB DC + auto SFT & $1.36 \pm 0.54$ & $1.02 \pm 0.34$ & + & 4 & NS \\
\hline
\end{tabular}

Clusters are generated by mixing SF DC with auto or allo peripheral blood T cells, or by mixing blood DC with auto or allo SF T cells. $N$, the number of experiments. P, Student $t$ test. ${ }^{*}$ T4/T8 ratio in SFM population. ${ }^{\ddagger}$ T4/T8 ratio of the cells embraced by a central DC.

activation is more dramatic than in the autologous response; $\sim 50 \%$ of the cells in the background are blasts at $1 \mathrm{wk}$. The cluster reaction is an in vitro phenomenon, but because $T$ cells are always contaminated with a few DC, we cannot exclude that a small percentage of DC are clustered in vivo in either blood or synovial fluid.

Cultured RA SFM differ from the blood autologous and allogeneic MLR in several ways. Spontaneous clusters form efficiently within $48 \mathrm{~h}$, but consistently show a T4/T8 ratio of $<$ 1.0. Most contain variable numbers of Leu $7+$ cells. The total of T4, T8, and Leu 7 cells in a cluster always exceeds $100 \%$, suggesting a portion are double labeled. In fact, a majority of the Leu 7 cells simultaneously display the CD8 marker. The DC/T cell clusters formed from PBM behave like immunologic units, whereas the clusters from RA SFM seem inert. After $\mathbf{4 8} \mathrm{h}$ in culture they slowly disassemble, without evidence of $T$ cell blast formation, and activation markers (transferrin receptor, IL-2 receptor, or Ia) were not seen on either the T cells or DC. The DCs remain intact, however, and can reform clusters with the addition of fresh blood or synovial fluid $T$ cells (data not shown). These properties of the RA SFM clusters could reflect either a DC or a $T$ cell abnormality. However, the DC which were inert in autologous SF clusters supported a near normal blastogenic response when cultured with autologous or allogeneic peripheral blood $\mathrm{T}$ cells, or allogeneic synovial fluid $T$ cells. Conversely, synovial fluid $T$ cells could respond to autologous blood DC or allogeneic blood or synovial fluid DC, but in each instance the proportion of CD4 cells in the cluster was less with SF elements than seen with mixtures of whole blood cells. The progression to blastogenesis and the appearance of $\mathrm{T}$ cell activation markers was also similar, although a smaller number of cells showed these features. Moreover, the experiments in the patient with active tuberculosis (see Results) indicate that synovial fluid DC are immunocompetent and can preferentially react with the appropriate $T$ cells when challenged with the correct antigen (PPD in this case).

The different responses of SF DC to autologous, allogeneic and protein antigens might reflect reactions utilizing separate populations of DC, especially in autologous reactions where some DC were not in clusters. Since we have no data on isolated clusters this possibility cannot be excluded. However, in the autologous response of untreated, newly diagnosed cases of RA (three examples) almost every available DC was clustered. This was also the case in antigen driven (allo and PPD) responses. Therefore, there were no DC available to react with other T cells. Moreover, each type of reaction has a characteristic T4/T8 ratio and there was little variation in the ratio from cluster to cluster. Such constancy would not be expected if the clusters were forming simultaneously with functionally differ- ent DC subsets. A more likely explanation is that the same DC engage separate sets of $T$ cells, selected at least in part by the stimulus (auto-, allo-, or antigen).

The failure of the T cells in RA SFM clusters to proliferate might reflect the presence of IL-1 and IL-2 inhibitors (31). Inflammatory synovial fluids do contain such inhibitors, but they are generally weak and unlikely to block the concentrations of interleukins used to stimulate the clusters. Although the phenotype of clustered RA T cells was unaltered by the addition of rIL-1, rIL-2, or rIFN-gamma, alone or in combination, the interleukins did have some effect because the $T$ cells in the cluster increased in number and bound more tightly to the DC. More surprising was the acquisition of surface T9 and Tac on a portion of the interleukin treated DC. Similar alterations were observed in isolated DC, making it unlikely that these surface glycoproteins were transferred from $T$ cells in the cluster, but we cannot exclude a prior contact. Tac and T9 molecules were also seen after $48 \mathrm{~h}$ on DC in the clusters formed in the allo-MLR.

NK play an important immunoregulatory role. Murine DC-T cell clusters are the targets for NK induced suppression of $T$ cell proliferation and a population of cells with dual markers (NK and CD8) can block T cell dependent B cell proliferation $(32,33)$. Leu $7+/ T 8+$ cells are regularly found in RA effusions and synovial fluid clusters, but not within MLR clusters made from blood cells of normals or rheumatoid patients. Similar double labeled cells are significantly increased in the circulating mononuclear cells of patients with the acquired immune deficiency syndrome, AIDS related complex, and other ongoing virus infections (34). A viral etiology of RA, while attractive, is unproven (35). Perhaps in the rheumatoid joint these cells serve to downregulate a potentially damaging ongoing immune reaction by interacting with a constituent in the cluster.

The $T$ cells in RA synovial effusions respond poorly to antigens and IL-2 and make lesser amounts of IL-2 and gamma-interferon than normal blood lymphocytes when stimulated. Although many have cell surface activation markers, they generally lack detectable transferrin receptors, are small in size and disproportionately more cells display Ia than IL-2 receptor (36-39). These attributes suggest that a portion of the synovial lymphocytes were previously activated and now appear as memory cells (39). A dissection of the CD4 population in inflammatory joint effusions shows a conspicuous decrease in the $2 \mathrm{H} 4+$ subset, which are suppressor inducers and are the primary responding cell in the AMLR. Instead the predominant CD4 cell has the 4B4 phenotype of a memory cell (40, 41). Based on this information one might anticipate that the CD4 cells in the RA SFM clusters would be primarily of the 

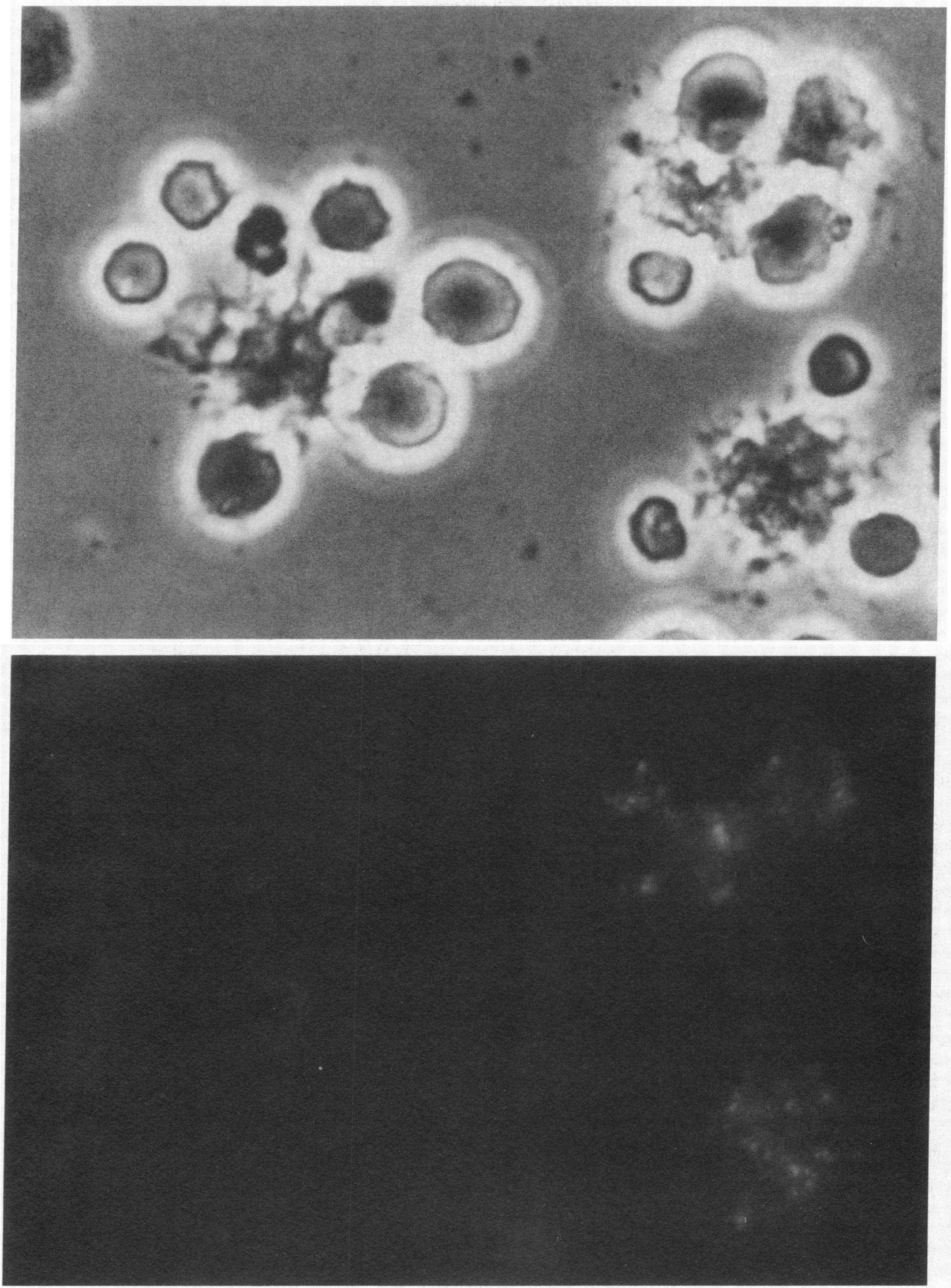

Figure 4. (A) Phase contrast micrograph showing three clusters in a 96-h allo-MLR culture (synovial fluid DC + allo blood T). Note some of the lymphocytes have increased in size, an indication of blastogenesis. (B) Paired immunofluorescent micrograph showing that two of the three clusters (upper and lower right) stain positive for Tac. Note that the upper right DC has more Tac in the area facing the $\mathrm{T}$ lymphocyte that is Tac positive $(\times 1,000)$. 

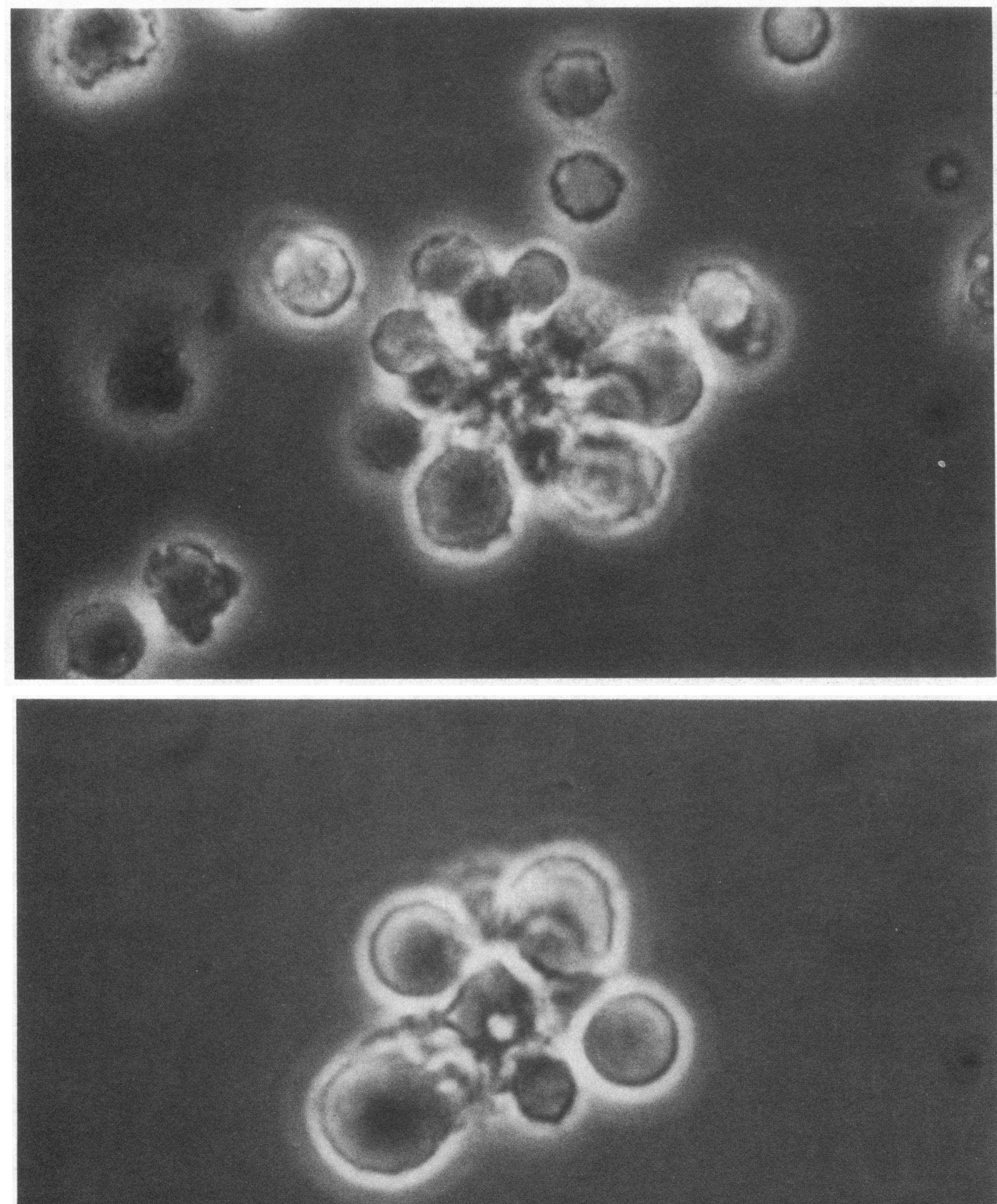

Figure 5. Paired phase contrast micrographs (left panels) and fluorescent micrographs (right panels) of clusters taken at $48 \mathrm{~h}$ from a culture of synovial fluid mononuclear cells containing $2 \mu \mathrm{g} / \mathrm{ml}$ of PPD. The patient had RA and active TB. Note that only one DC (8C4 positive cell; upper right) is in the center of a cluster that is surrounded by more than $10 \mathrm{~T}$ cells and that the $\mathrm{T}$ cell blasts in the cluster stain with MAb T9 (lower right panel). 

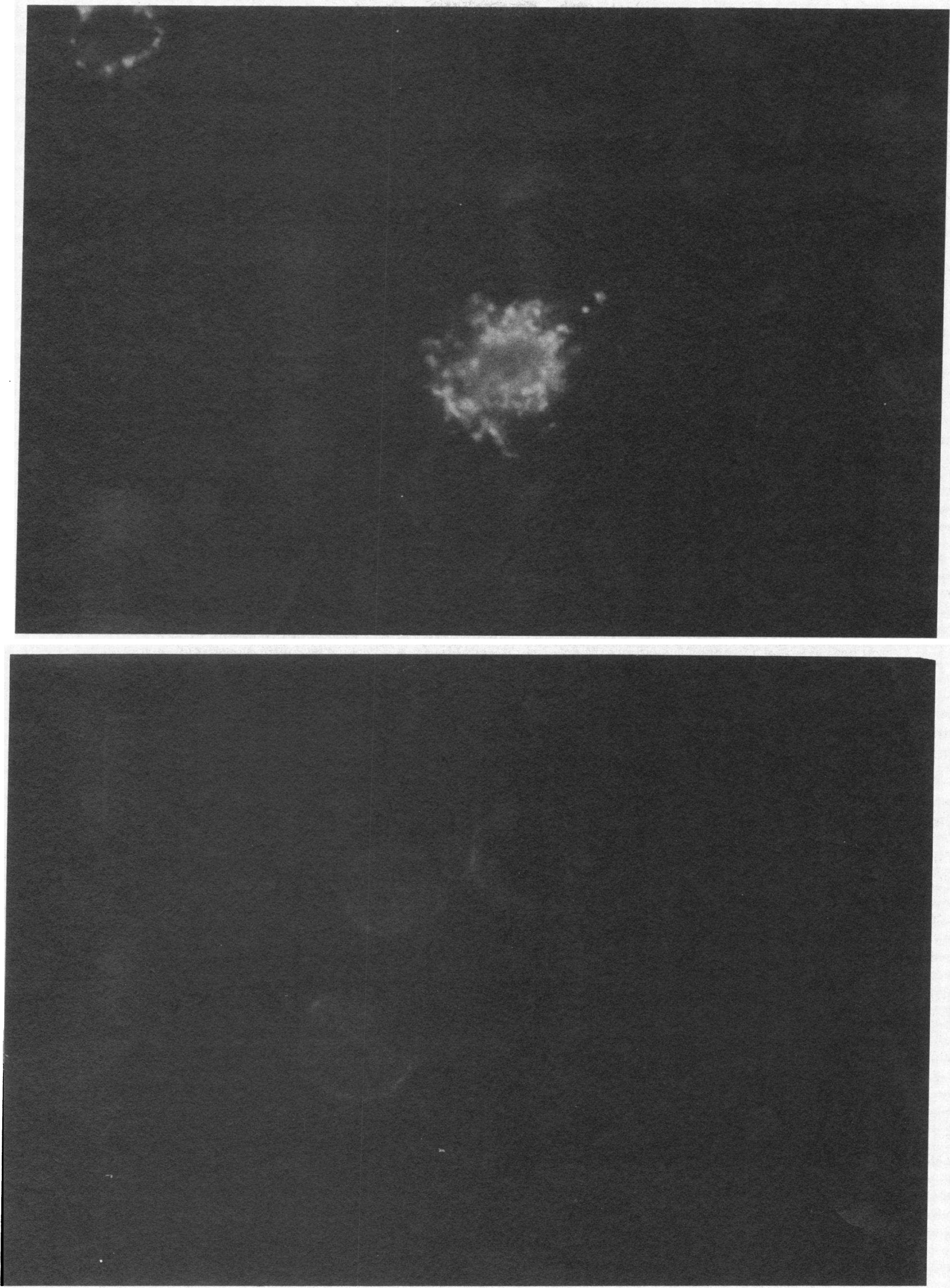

Figure 5 (Continued) 
4B4 type. This is what we have found (preliminary observations).

A study of the properties of memory $T$ lymphocytes isolated from murine primary MLR by Inaba showed that the lymphoblasts from these cultures became small in size, lost responsiveness to IL-2, but retained reactivity to the original alloantigen. In addition, such memory lymphocytes quickly formed aggregates with syngeneic DC, but these clusters disassembled within hours and failed to proliferate $(4,42)$ in a manner analogous to the SF clusters. Thus, the inert nature of the RA SFM clusters probably reflects both the paucity of $T$ cells in RA synovial fluid that can respond to autologous stimulation (2H4+ cells) and increased numbers of previously activated (4B4+ memory) $\mathrm{T}$ cells. We cannot exclude subtle defects in the DC of RA joint effusions, but believe they are functional by virtue of their ability to cluster with and support the proliferation of allogeneic or antigen-specific $\mathrm{T}$ cells. The fact that the clusters proliferate when exposed to $10 \%$ autologous synovial fluid suggests that an antigen(s) may be responsible, but inflammatory joint fluids contain a number of mitogens and growth factors that could provide an alternative explanation for the blastogenic response $(36,43)$. We are not yet able to choose between these alternatives, but hope to clarify this important point.

\section{Acknowledgments}

The expert secretarial skills of Denise Smith are acknowledged. Valuable discussions were held with R. M. Steinman and H. G. Bluestein.

These studies could not have been accomplished without the generous cooperation of the rheumatologists at the Kaiser Permanente, San Diego Medical Center (J. Scavulli and A. Cohen); the Naval Regional Medical Center, San Diego (R. Klofkorn, B. Anderson, and C. Counihan); and the practices of $H$. Krumholtz and R. Kaplan. Supported in part by National Institutes of Health grants AR-14916 and AR-25719 and Arthritis Foundation Biomedical Center Research grant.

\section{References}

1. Steinman, R. M., and Z. A. Cohn. 1973. Identification of a novel cell type in peripheral lymphoid organs of mice. I. Morphology, quantitation and tissue distribution. J. Exp. Med. 137:1142-1162.

2. Guidos, C., M. Wong, and K. C. Lee. 1984. A comparison of the stimulatory activities of lymphoid dendritic cells and macrophages in $\mathrm{T}$ cell proliferative responses to various antigens. J. Immunol. 133:1179-1184.

3. Inaba, K., and R. M. Steinman. 1985. Protein specific helper T lymphocyte formation initiated by D.C. Science (Wash. DC) 229:476-478.

4. Inaba, K., S. Koide, and R. M. Steinman. 1985. Properties of memory $\mathrm{T}$ lymphocyte isolated from the mixed leukocyte reaction. Proc. Natl. Acad. Sci. USA. 82:7686-7690.

5. Rollinghoff, M., K. Pfizenmaier, and H. Wagner. 1982. T-T cell interaction during cytotoxic $T$ cell responses. IV. Murine lymphoid dendritic cells are powerful stimulators for helper T lymphocytes. Eur. J. Immunol. 12:337-342.

6. Nussenzweig, M. C., R. M. Steinman, B. Gutchinov, and Z. A. Cohn. 1980. Dendritic cells are accessory cells for the development of anti-trinitrophenyl cytotoxic T lymphocytes. J. Exp. Med. 152:10701084.

7. Klinkert, W. E., J. H. LaBadie, and W. E. Bowers. 1982. Accessory and stimulating properties of dendritic cells and macrophages isolated from various rat tissue. J. Exp. Med. 156:1-19.

8. Nussenzweig, M. C., and R. M. Steinman. 1980. Contribution of DC to stimulation of the murine syngeneic MLR. J. Exp. Med. 151:1196-1212.
9. Steinman, R. M., and M. D. Witmer. 1978. Lymphoid dendritic cells are potent stimulators of the primary mixed leukocyte reaction in mice. Proc. Natl. Acad. Sci. USA. 10:5132-5136.

10. Van-Voorhis, W. C., L. S. Hair, R. M. Steinman, and G. Kaplan. 1982. Human dendritic cells: Enrichment and characterization from peripheral blood. J. Exp. Med. 155:1172-1187.

11. Green, J., and J. Randall. 1985. Interactions between T helper cells and dendritic cells during the rat mixed lymphocyte reaction. $J$. Exp. Med. 162:1546-1560.

12. Inaba, K., and R. M. Steinman. 1984. Resting and sensitized T lymphocytes exhibit distinct stimulatory (Ag-presenting cell) requirement for growth and lymphokine release. J. Exp. Med. 160:17171735.

13. Steinman, R. M., B. Gutchinov, M. D. Witmer, and M. C. Nussenzweig. 1983. Dendritic cells are the principal stimulators of the primary mixed leukocyte reaction in mice. J. Exp. Med. 157:613-627.

14. Austyn, J. M., R. M. Steinman, D. E. Weinstein, A. GranelliPiperno, and M. A. Palladino. 1983. Dendritic cells initiate a two-stage mechanism for T lymphocyte proliferation. J. Exp. Med. 157:11011115.

15. Hunig, J. 1983. The role of accessory cells in polyclonal T cell activation. II. Induction of IL-2 responsiveness required cell-cell contact. Eur. J. Immunol. 13:596-601.

16. Inaba, K., J. W. Young, and R. M. Steinman. 1987. Direct activation of CD8+ cytotoxic T lymphocytes by dendritic cells. J. Exp. Med. 166:182-194.

17. Harding, B., and S. C. Knight. 1986. The distribution of dendritic cells in the synovial fluids of patients with arthritis. Clin. Exp. Immunol. 63:594-600.

18. Knight, S. C., J. Farrant, A. Bryant, A. J. Edwards, S. Burman, A. Lever, J. Clarke, and A. D. Webster. 1986. Non-adherent, low density cells from human peripheral blood contain dendritic cells and monocytes, both with veiled morphology. Immunology. 57:595-603.

19. Spry, C. J., A. J. Pflug, G. Janossy, and J. H. Humphrey. 1980. Large mononuclear (vieled) cells like 'Ia-like' membrane antigens in human afferent lymph. Clin. Exp. Immunol. 39:750-755.

20. de-Vere-Tyndall, A., S. C. Knight, A. J. Edwards, and J. Clarke. 1983. Vieled dendritic cells in synovial fluid. (Letter). Lancet. i:472473.

21. Zvaifler, N. J., R. M. Steinman, G. Kaplan, L. L. Lau, and M. Rivelis. 1985. Identification of immunostimulating DC in synovial effusions of patients with RA. J. Clin. Invest. 76:789-800.

22. Waalen, K., J. Thoen, O. Forre, T. Hovig, J. Teigland, and J. B. Natvig. 1986. Rheumatoid synovial dendritic cells as stimulators in allogeneic and autologous mixed leukocyte reactions. Comparison with autologous monocytes as stimulator cells. Scand. J. Immunol. 23:233-241.

23. Crow, M. K., and H. G. Kunkel. 1982. Human dendritic cells: Major stimulators of the autologous and allogeneic mixed leukocyte reactions. Clin. Exp. Immunol. 49:338-341.

24. Steinman, R. M., and M. C. Nussenzweig. 1980. Dendritic cells: features and functions. Immunol. Rev. 53:127-147.

25. Freer, S. M. 1984. A permanent wet-mount for fluorescent microscopy of surface stained lymphoid cells. J. Immunol. Methods. 66:187-188.

26. Wahl, S. M., D. L. Rosenstreich, and J. J. Oppenheim. 1976. Separation of human lymphocytes by E Rosette sedimentation. In In Vitro Methods in Cell-Mediated \& Tumor Immunity. R. B. Bloom and J. R. David, editors. Academic Press, Inc., New York. 231-243.

27. Greaves, M. F., G. Janossy, and P. Curtis. 1976. Purifications of human $T$ lymphocytes using nylon fiber column. In In Vitro Methods in Cell-Mediated \& Tumor Immunity. R. B. Bloom and J. R. David, editors. Academic Press, Inc., New York. 217-229.

28. Böyum, A. 1983. Isolation of human blood monocytes with nycodenz, a new ionic iodinated gradient medium. Scand. J. Immunol. 17:429-436.

29. Iwasaki, H., M. Taniguchi, and N. Shinohara. 1985. Recognition of alloantigen by cytotoxic $\mathrm{T}$ cell precursors is independent of the function of Ia+ cells. J. Immunol. 134:3592-3596. 
30. Takai, Y., G. G. Wong, S. C. Clark, S. J. Burakoff, and S. H. Herrmann. 1988. B cell stimulatory factor-2 is involved in the differentiation of cytotoxic T lymphocytes. J. Immunol. 140:508-512.

31. Lotz, M., D. C. Tsoukas, C. A. Robinson, C. A. Dinarello, D. A. Carson, and J. H. Vaughan. 1986. Basis for defective responses of rheumatoid arthritis synovial fluid lymphocytes to anti-CD3 (T3) antibodies. J. Clin. Invest. 78:713-721.

32. Shah, P. D., S. M. Gilbertson, and D. A. Rowley. 1985. Dendritic cells that have been treated with $\mathrm{Ag}$ are targets for natural killer cells. J. Exp. Med. 162:625-636.

33. Clemente, L. T., C. E. Grossi, and G. L. Gartland. 1984. Morphologic features of subpopulation of Leu $2+$ cells that suppresses B cell differentiation. J. Immunol. 133:2461-2468.

34. Plaezer-Marshall, S., C. A. Spina, J. V. Giorgi, R. Mitsuyasu, P. Wolfe, M. Gottlieb, and G. Beall. 1987. Alterations in cytotoxic and phenotypic subsets of NK cells in acquired immune deficiency syndrome. J. Clin. Immunol. 7:16-23.

35. Bluestein, H. G., and F. Hasler. 1984. Epstein-Barr virus and RA. Surv. Immunol. Res. 3:70-77.

36. Abdel-Nour, A. N., C. J. Elson, and P. A. Dieppe. 1986. Proliferative response of $\mathrm{T}$ cell lines grown from joint fluids of patients with RA and other arthritides. Immunol. Lett. 12:329-333.

37. Burmester, G. R., D. T. Y. Yu, A.-M. Irani, H. G. Kunkel, and R. J. Winchester. 1981. Ia+ $T$ cells in synovial fluid and tissues of patients with rheumatoid arthritis. Arthritis Rheum. 24:1370-1376.
38. Peters, J. 1986. Functional capacities of $T$ lymphocyte subset from synovial fluid and blood in RA. Ann. Rheum. Dis. 45:539-545.

39. Hemler, M. E., F. Sanchez-Madrid, T. J. Flotte, A. M. Krensky, S. J. Burakoff, A. K. Bhan, T. J. Springer, and J. L. Strominger. 1984. Glycoproteins of 210,000 and $130,000 \mathrm{MW}$ on activated T cells: Cell distribution and antigenic relation to components on resting cells and T cell line. J. Immunol. 132:3011-3018.

40. Sanders, M. E., M. W. Makgoba, S. O. Sharrow, D. Stephany, T. A. Springer, H. A. Young, and S. Shaw. 1988. Human memory T lymphocytes express increased levels of three cell adhesion molecules (LFA-3, CD3, and LFA-1) and three other molecules (UCHL1, CDw29, and Pgp-1) and have enhanced IFN- $\gamma$ production. J. Immunol. 140:1401-1407.

41. Morimoto, C., N. L. Letvin, A. W. Boyd, M. Hagan, H. M. Brown, M. M. Kornacki, and S. F. Schlossman. 1985. The isolation and characterization of the human helper inducer $\mathrm{T}$ cell subset. $J$. Immunol. 134:3762-3770.

42. Inaba, K., and R. M. Steinman. 1986. Accessory cell T lymphocyte interactions. $\mathrm{Ag}$ dependent and independent clustering. $J$. Exp. Med. 163:247-261.

43. Firestein, G. S., W. D. Xu, K. Townsend, A. Glasebrook, D. H. Broide, and N. J. Zvaifler. 1988. Cytokines in chronic inflammatory arthritis. I. Failure to detect T cell lymphokines (IL-2 and IL-3) and presence of CSF-1 and a novel mast cell growth factor in rheumatoid synovitis. J. Exp. Med. In press. 